\title{
A "Snap" of portable media use among children two years and younger in a developing country
}

\author{
Rana Sharara-Chami*, Zavi Lakissian, Heba Al-Rayess and Rose-Mary Boustany \\ Department of Pediatrics and Adolescent Medicine, American University of Beirut Medical Center, Beirut, Lebanon
}

\begin{abstract}
Introduction: Tablets and smartphones have become ubiquitous in the lives of young children. Literature from developed countries has shown both positive and negative long-term effects of screen exposure and use on developmental milestones; however, no information is available for developing countries. This study assesses the prevalence of device use among children 2 years and younger and parent perception of the impact of these devices.

Methods: Parents of healthy children ( $\leq 2$ years) were approached at an out-patient pediatric clinic in an urban teaching hospital between May-July 2016. After consenting, parents were asked to interview with one of the investigators based on a 40-item questionnaire divided into 4 main sections: demographics, availability and accessibility of portable devices, use of devices and parents' perception.

Results: 71 questionnaires were analyzed. Most families lived in urban areas (73\%) and at least one parent was university-educated (82\%). All households had at least 1 media device; $65 \%$ of children were allowed to use devices before the age of $2-28 \%$ independently. Most children (62\%) were allowed access for $<1$ hour/day: $25 \%$ for entertainment, most commonly YouTube (54\%). Majority of parents (80\%) believed the use of portable media devices had a negative impact on their child, yet $60 \%$ perceived their children were calmer when using them and $44 \%$ got irritated when devices were taken away.

Conclusion: Among well-educated urban families in a developing country, exposure of children to mobile media devices starts as early as infancy, despite parental perception of their potentially negative impact on the child.
\end{abstract}

\begin{abstract}
Abbreviations: AAP: American Academy of Pediatrics; DVD: Digital Versatile Disc
\end{abstract}

\section{Introduction}

Heads down, staring at the screen: this is how many children of different ages nowadays spend hours of their time. This phenomenon has become increasingly common in all parts of the world, whether at home, during social gatherings, at restaurants or in transit. The American Academy of Pediatrics (AAP) "discourages[s] the use of media by children under the age of two [1]". Yet, a recent study ${ }^{2}$ in the United States found most children have used a device daily by the age of 2 and have spent comparable screen time on television and mobile devices. According to the same study, $96 \%$ of children living in an urban, low-income, minority community used a mobile device by the age of 4 years, mostly without help and comfortably used multiple media platforms at once [2]. Despite the AAP's recommendation, tablets and smart phones are spreading among today's children to reach even the smallest fingers.

Before the emergence of portable media devices, children had been exposed to traditional media, such as television and Digital Versatile Disc (DVD) videos. Although a lot of research has been published regarding the effect of traditional media on young children [3], there is comparably less research on the effects of modern media technologies. A number of studies have found negative associations between screen time and cognitive development outcomes in older children, including short-term memory skills, academic achievement, and language development [4,5]. As readily accessible and userfriendly as these devices are, it is imperative that we glean the weight of their impact. Strong supporting evidence is lacking in order to tip the scale one way or the other with regards to the impact of hand-held portable devices on children's development. Moreover, these newer devices vary significantly from traditional media by how interactive the users can be versus the passivity while staring at a television screen. This interactivity allows for a so called "I did it!" response, which has been explained as the "delight a child gets from touching a screen and making something happen" [6], similar to playing with more tactile traditional toys i.e. blocks. The latter is one of the reasons why some are calling for a revision of the AAP's 2011 recommendations in favor of limited use of up to 1 hour of interactive media for children younger than 2 years of age ${ }^{6}$. Recently, researchers have been investigating the effect of new touch screens on their youngest users. Some observed positive effects on child development when screens were used in an interactive way, such as learning new words and concepts [7]. It was also suggested that fine motor skills were better in children who were scrolling [8]. A robust assessment of the impact of portable media on children's development would require longitudinal prospective studies. This is an initial assessment of a survey conducted with parents of children 2 years and younger seen at a pediatric out-patient clinic in Beirut, Lebanon. In this paper, we attempt to describe the prevalence

*Correspondence to: Rana Sharara-Chami, Department of Pediatrics and Adolescent Medicine, American University of Beirut Medical Center, P.O. Box 11-0236 Riad El Solh 11072020 Beirut, Lebanon, Tel: +961-1-350000 extension 5536; Fax +961-1-370781; E-mail: rsharara@aub.edu.lb

\section{Keywords: Media, Screen Time}

Received: January 22, 2019; Accepted: January 28, 2019; Published: January 31, 2019 
of portable media use among this population and parent perceptions about the use of these devices by their children.

\section{Methods}

\section{Study design, setting and sample:}

This is cross-sectional study with a convenience sample of 71 children between the ages of 2 months to 2 years who visited an outpatient pediatric clinic of a tertiary educational medical center in an urban setting in Beirut between May-July 2016. The clinic is visited by patients of all socioeconomic levels, which allowed for heterogeneity in the sample. The sample included healthy, term children two years and younger, with no comorbid conditions or developmental delay, living in Lebanon for the foreseeable future, available for follow-up and accompanied by a parent who is 18 -years or older and fluent in spoken and written English.

The study was approved by the Institutional Review Board of the American University of Beirut. Parents were approached by one of the investigators while waiting for their appointment. Following written consent, they were interviewed by the investigator based on a 40 -item questionnaire. This included 4 main sections: demographics, availability of and access to portable devices, use of devices and parent perceptions. Questions were mostly close-ended with multiple choice or binary responses. The initial questionnaire was refined and restructured between February and May of 2016 through an iterative process of pretesting and analysis where experts, including pediatricians and pediatric neurologists, were asked to weigh in on the relevance of the questions and provide feedback.

\section{Target outcomes}

1. Portable device availability and accessibility: Parents were asked to indicate the number of traditional media devices i.e. television, DVD, computers in the household, as well as hand-held portable devices including smart phones, tablets, game consoles (PlayStation ${ }^{\circ}$, $\mathrm{Wii}^{\oplus}, \mathrm{X}-$ box $\left.^{\oplus}\right)$ and laptops. They were asked if the child had access to these devices, and whether some were solely purchased for the child.

2. Device use: Parents were asked when the child was initially exposed to media ( $<3$ months, 3-6 months, 6 months-1 year, 1-2 years) and how often and under what circumstances devices were made available to the child, whether the device is "always available", "given for strictly determined hours every day", "given to the child upon demand", "given only when caregiver is busy", "given outside the home but restricted at home". Parents were asked where the child was allowed to use these devices (only at home? At the day-care?) and for how many hours a day ( $<1$ hour, 1-2 hours, 2-5 hours, $>5$ hours). Responders were asked to indicate the content of the media the child was exposed to (YouTube, educational applications, Skype, games, other), and lastly if they had observed the child imitating what they had seen or heard while using a media device.

To assess the child's early dependency on devices, these questions were asked: "is your child calmer when he/she uses the device?", "does your child get irritated when the device is taken away?", and "does your child prefer spending time on the device instead of regular play?"; to elaborate more on the last question, parents were asked if the child "played with other children", "was read to by an adult", "played outdoors" or "played with traditional toys".

3. Parent perception of the use of media devices: Parents were queried about why they allowed their young children to use media devices and whether they thought "the child will learn more skills", "the activity is safe and will keep the peace", "it provides entertainment similar to other toys", "all children need them these days", or "to keep in touch with relatives who are away." To help contextualize this better, they were asked to describe the time spent with their child each day and what they did during that time. Additionally, parents were asked about their perceptions of any possible negative impact of exposure to hand-held media devices at a young age. Answers to this open-ended question were categorized by type of potential harm: (1) behavioral, such as exacerbated tantrums; (2) developmental, such as subnormal IQ or autism; (3) physical, such as impaired vision and risks associated with lack of physical activity; and lastly (4) exposure to potentially damaging content, if left unsupervised, while using the device. Parents were asked whether they perceived any positive effects on their child that they attributed to time spent on portable media devices, specifically: learning new vocabulary, enhanced speech acquisition, introduction of new concepts, or improvement in social skills.

\section{Sample Size}

As a descriptive, exploratory cross-sectional study, we used nonprobability convenience sampling. Seventy-one children were included in the study, the sample estimate is based on a $95 \%$ confidence interval with a $5 \%$ margin of error.

\section{Statistical Analysis}

Statistical analysis was accomplished using SPSS software version 23 (IBM SPSS Statistics, IBM Corporation. Descriptive quantitative analyses were performed to summarize data gathered by the questionnaire (Tables 1-4).

\section{Results}

Seventy-one interviews were conducted between May-July 2016. The majority of families lived in urban areas (69\%) and households included 5 (1.3) members. Twenty-eight percent of children in the sample were younger than 7 months old, $37 \%$ were $7-12$ months, $22 \%$ 13-18 months and 13\% were 19-24 months old. Sixty-one per cent were boys. Eighty-two percent of couples had at least one universityeducated parent. In $49 \%$ of households, the primary spoken language was Arabic, $18 \%$ were bilingual and $13 \%$ multilingual ( $\geq 3$ languages). Ninety-three percent of fathers and $41 \%$ of mothers were fully employed, working on average 5-9 hours per day; $37 \%$ of mothers were housewives. On average, parents noted 3 (1.2) hours of bonding time with the child. All households had at least 1 media device. Initially, we asked parents about daily traditional media and play: $58 \%$ of children watched television, $59 \%$ played with other children, $44 \%$ of parents read to their child, and $80 \%$ spent time playing with traditional toys and $41 \%$ played outdoors. Sixty-nine percent of children were allowed to use devices before the age of $2-28 \%$ independently. Thirty-one percent of parents allowed access to devices for a restricted amount of time: most children were allowed access for less than an hour a day $(62 \%)$. The reasons for using the device were for entertainment purposes $(25 \%)$, educational activities (21\%), and for communicating with relatives abroad (10\%). The most commonly used application was YouTube (54\%), followed by Skype (28\%) and other educational applications (23\%). A third of parents (35\%) thought that their children preferred screen-time to regular play. Seventy-three percent of parents controlled and monitored content exposure, and 63\% were present with the child when they were using portable media. A majority of parents ( $80 \%$ ) believed use of portable media had a negative 
Table 1. Demographic Characteristics

\begin{tabular}{|c|c|c|c|}
\hline Demographic Characteristics & & $n(\%)$ & Total Sample $(\mathrm{N}=71)$ \\
\hline Child's Gender & $\begin{array}{l}\text { Male } \\
\text { Female }\end{array}$ & $\begin{array}{l}43(61 \%) \\
28(39 \%)\end{array}$ & \\
\hline Age Groups & $\begin{array}{l}<7 \text { Months } \\
\text { 7-12 Months } \\
\text { 12-18 Months } \\
\text { 19-24 Months }\end{array}$ & $\begin{array}{c}20(28 \%) \\
26(37 \%) \\
16(22 \%) \\
9(13 \%)\end{array}$ & \\
\hline Rank Among Siblings & $\begin{array}{l}\text { First } \\
\text { Second } \\
\text { Third } \\
\text { Fourth }\end{array}$ & $\begin{array}{c}43(61 \%) \\
19(27 \%) \\
6(8 \%) \\
3(4 \%)\end{array}$ & \\
\hline Members of Household & $\begin{array}{l}\text { Three } \\
\text { Four } \\
\text { Five } \\
\text { Six } \\
>\text { Six } \\
\end{array}$ & $\begin{array}{c}16(22 \%) \\
20(28 \%) \\
15(21 \%) \\
15(21 \%) \\
4(6 \%)\end{array}$ & \\
\hline Parental Employment & $\begin{array}{l}\text { Fathers } \\
\text { Employed } \\
\text { Working Hours [Mean (SD)] } \\
\text { Unemployed } \\
\text { Mothers } \\
\text { Employed } \\
\text { Working Hours [Mean (SD)] } \\
\text { Unemployed }\end{array}$ & $\begin{array}{c}66(93 \%) \\
9(2) \\
5(7 \%) \\
\\
29(41 \%) \\
5(5) \\
42(59 \%)\end{array}$ & \\
\hline Parents' Education & $\begin{array}{l}\text { Fathers } \\
\text { High School } \\
\text { University } \\
\text { Undisclosed } \\
\text { Mothers } \\
\text { High School } \\
\text { University } \\
\text { Undisclosed }\end{array}$ & $\begin{array}{c}10(14 \%) \\
58(82 \%) \\
3(4 \%) \\
10(14 \%) \\
56(79 \%) \\
5(7 \%)\end{array}$ & \\
\hline Language Spoken at Home & $\begin{array}{l}\text { Arabic } \\
\text { English } \\
\text { French } \\
\text { Bilingual } \\
\text { Multilingual }\end{array}$ & $\begin{array}{l}35(49 \%) \\
10(14 \%) \\
3(4 \%) \\
13(18 \%) \\
9(13 \%)\end{array}$ & \\
\hline
\end{tabular}

Table 2. Device Availability and Access

\begin{tabular}{|c|c|c|c|}
\hline Device Availability \& Access & & $n(\%)$ & \\
\hline 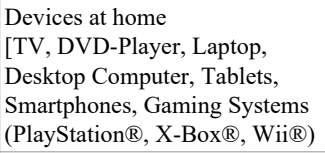 & $\begin{array}{l}\text { Only TV + Smartphones } \\
\text { All } \\
\text { All except gaming systems }\end{array}$ & $\begin{array}{l}12(17 \%) \\
10(14 \%) \\
47(67 \%)\end{array}$ & $\mathrm{N}=70$ \\
\hline $\begin{array}{l}\text { What other activities does the } \\
\text { child engage in? }\end{array}$ & $\begin{array}{l}\text { Watching TV } \\
\text { Playing with other children } \\
\text { Reading with an adult } \\
\text { Playing with traditional toys } \\
\text { Playing outdoors }\end{array}$ & $\begin{array}{l}41(58 \%) \\
42(59 \%) \\
31(44 \%) \\
57(80 \%) \\
29(41 \%)\end{array}$ & $\mathrm{N}=66$ \\
\hline $\begin{array}{l}\text { When did the child start using } \\
\text { devices? }\end{array}$ & $\begin{array}{l}\text { Does not use devices } \\
<6 \text { Months of age } \\
6-12 \text { Months of age } \\
>12 \text { Months of Age }\end{array}$ & $\begin{array}{c}1(1.4 \%) \\
13(18.3 \%) \\
29(41 \%) \\
7(10 \%)\end{array}$ & $\mathrm{N}=50$ \\
\hline Does the child own a device? & $\begin{array}{l}\text { Yes } \\
\text { No }\end{array}$ & $\begin{array}{l}12(17 \%) \\
59(83 \%)\end{array}$ & $\mathrm{N}=71$ \\
\hline $\begin{array}{l}\text { Since when does the child } \\
\text { own a device? }\end{array}$ & $\begin{array}{l}<7 \text { Months of age } \\
7-12 \text { Months of age } \\
>13 \text { Months of age }\end{array}$ & $\begin{array}{l}3(4.2 \%) \\
3(4.2 \%) \\
3(4.2 \%)\end{array}$ & $\mathrm{N}=9$ \\
\hline
\end{tabular}

impact on their child (e.g. vision impairment, developmental delays, exposure to inappropriate content), yet $59 \%$ perceived their children were calmer when using these devices and $44 \%$ displayed irritability when the device was taken away. Additionally, $41 \%$ of parents noticed their child imitated content, learned new vocabulary (22\%), acquired new concepts (21\%), had improved speech (13\%) and displayed better social engagement (18\%).

\section{Discussion}

The primary goal of this study was to assess exposure to and prevalence of use of media devices in children 2 years and younger and parent perception regarding this phenomenon. Analyses revealed prevalent exposure to and use of mobile media devices as early as in infancy in highly educated urban families. Children predominantly 
Table 3. Device Use

\begin{tabular}{|c|c|c|c|}
\hline Parent Perception of Device Use & & $n(\%)$ & \\
\hline $\begin{array}{l}\text { How many hours per day do you spend } \\
\text { bonding with your child? }\end{array}$ & $\begin{array}{l}\text { All day } \\
<3 \text { Hours } \\
3-6 \text { Hours } \\
6-12 \text { Hours }\end{array}$ & $\begin{array}{c}24(34 \%) \\
3(4 \%) \\
21(30 \%) \\
22(31 \%)\end{array}$ & $\mathrm{N}=70$ \\
\hline $\begin{array}{l}\text { Do you spend time on media devices with } \\
\text { your child? }\end{array}$ & $\begin{array}{l}\text { Yes } \\
\text { No }\end{array}$ & $\begin{array}{l}45(63 \%) \\
8(11 \%)\end{array}$ & $\mathrm{N}=53$ \\
\hline $\begin{array}{l}\text { How many hours per day do you spend } \\
\text { on media devices? }\end{array}$ & $\begin{array}{l}<1 \text { Hour } \\
1-2 \text { Hours } \\
2-5 \text { Hours } \\
>5 \text { Hours }\end{array}$ & $\begin{array}{l}18(25 \%) \\
16(22 \%) \\
27(38 \%) \\
8(12 \%)\end{array}$ & $\mathrm{N}=69$ \\
\hline $\begin{array}{l}\text { Do you think you are using the devices more } \\
\text { than you should? }\end{array}$ & $\begin{array}{l}\text { Yes } \\
\text { No }\end{array}$ & $\begin{array}{l}29(41 \%) \\
37(52 \%)\end{array}$ & $\mathrm{N}=66$ \\
\hline $\begin{array}{l}\text { Do you think prolonged screen exposure } \\
\text { could impact your child } \\
\text { negatively? }\end{array}$ & $\begin{array}{l}\text { Yes } \\
\text { No }\end{array}$ & $\begin{array}{l}57(80 \%) \\
11(15 \%)\end{array}$ & $\mathrm{N}=68$ \\
\hline $\begin{array}{l}\text { Do you think your child is spending more } \\
\text { time on devices? }\end{array}$ & $\begin{array}{l}\text { Yes } \\
\text { No }\end{array}$ & $\begin{array}{c}6(9 \%) \\
50(70 \%)\end{array}$ & $\mathrm{N}=56$ \\
\hline $\begin{array}{l}\text { Do you think you are unable to control/ } \\
\text { monitor your child's use? }\end{array}$ & $\begin{array}{l}\text { Yes } \\
\text { No }\end{array}$ & $\begin{array}{c}56(79 \%) \\
6(9 \%)\end{array}$ & $\mathrm{N}=62$ \\
\hline $\begin{array}{l}\text { Do you think your child has learnt new } \\
\text { vocabulary while } \\
\text { using devices? }\end{array}$ & $\begin{array}{l}\text { Yes } \\
\text { No }\end{array}$ & $\begin{array}{l}16(23 \%) \\
36(5150\end{array}$ & $\mathrm{N}=52$ \\
\hline $\begin{array}{l}\text { Do you think your child has learnt new } \\
\text { concepts while using devices? }\end{array}$ & $\begin{array}{l}\text { Yes } \\
\text { No }\end{array}$ & $\begin{array}{l}15(21 \%) \\
32(45 \%)\end{array}$ & $\mathrm{N}=47$ \\
\hline \multirow[t]{2}{*}{$\begin{array}{l}\text { Do you think your child's speech has } \\
\text { improved while } \\
\text { using devices? }\end{array}$} & $\begin{array}{l}\text { Yes } \\
\text { No }\end{array}$ & $\begin{array}{c}9(13 \%) \\
14(20 \%)\end{array}$ & \\
\hline & No difference & $21(30 \%)$ & $\mathrm{N}=44$ \\
\hline $\begin{array}{l}\text { Do you think your child's social engagement } \\
\text { skills have } \\
\text { improved while using devices? }\end{array}$ & $\begin{array}{l}\text { Yes } \\
\text { No } \\
\text { No difference }\end{array}$ & $\begin{array}{l}13(18 \%) \\
12(17 \%) \\
16(23 \%)\end{array}$ & $\mathrm{N}=46$ \\
\hline
\end{tabular}

Table 4. Parent Perception of Device Use

\begin{tabular}{|c|c|c|c|}
\hline Parent Perception of Device Use & & $n(\%)$ & \\
\hline $\begin{array}{l}\text { How many hours per day do you spend } \\
\text { bonding with your child? }\end{array}$ & $\begin{array}{l}\text { All day } \\
<3 \text { Hours } \\
3-6 \text { Hours } \\
6-12 \text { Hours }\end{array}$ & $\begin{array}{c}24(34 \%) \\
3(4 \%) \\
21(30 \%) \\
22(31 \%)\end{array}$ & $\mathrm{N}=70$ \\
\hline $\begin{array}{l}\text { Do you spend time on media devices with } \\
\text { your child? }\end{array}$ & $\begin{array}{l}\text { Yes } \\
\text { No }\end{array}$ & $\begin{array}{l}45(63 \%) \\
8(11 \%)\end{array}$ & $\mathrm{N}=53$ \\
\hline $\begin{array}{l}\text { How many hours per day do you spend } \\
\text { on media devices? }\end{array}$ & $\begin{array}{l}<1 \text { Hour } \\
1-2 \text { Hours } \\
2-5 \text { Hours } \\
>5 \text { Hours }\end{array}$ & $\begin{array}{c}18(25 \%) \\
16(22 \%) \\
27(38 \%) \\
8(12 \%)\end{array}$ & $\mathrm{N}=69$ \\
\hline $\begin{array}{l}\text { Do you think you are using the devices more } \\
\text { than you should? }\end{array}$ & $\begin{array}{l}\text { Yes } \\
\text { No }\end{array}$ & $\begin{array}{l}29(41 \%) \\
37(52 \%)\end{array}$ & $\mathrm{N}=66$ \\
\hline $\begin{array}{l}\text { Do you think prolonged screen exposure } \\
\text { could impact your child } \\
\text { negatively? }\end{array}$ & $\begin{array}{l}\text { Yes } \\
\text { No }\end{array}$ & $\begin{array}{l}57(80 \%) \\
11(15 \%)\end{array}$ & $\mathrm{N}=68$ \\
\hline $\begin{array}{l}\text { Do you think your child is spending more } \\
\text { time on devices? }\end{array}$ & $\begin{array}{l}\text { Yes } \\
\text { No }\end{array}$ & $\begin{array}{c}6(9 \%) \\
50(70 \%)\end{array}$ & $\mathrm{N}=56$ \\
\hline $\begin{array}{l}\text { Do you think you are unable to control/ } \\
\text { monitor your child's use? }\end{array}$ & $\begin{array}{l}\text { Yes } \\
\text { No }\end{array}$ & $\begin{array}{c}56(79 \%) \\
6(9 \%)\end{array}$ & $\mathrm{N}=62$ \\
\hline $\begin{array}{l}\text { Do you think your child has learnt new } \\
\text { vocabulary while } \\
\text { using devices? }\end{array}$ & $\begin{array}{l}\text { Yes } \\
\text { No }\end{array}$ & $\begin{array}{l}16(23 \%) \\
36(5150\end{array}$ & $\mathrm{N}=52$ \\
\hline $\begin{array}{l}\text { Do you think your child has learnt new } \\
\text { concepts while using devices? }\end{array}$ & $\begin{array}{l}\text { Yes } \\
\text { No }\end{array}$ & $\begin{array}{l}15(21 \%) \\
32(45 \%)\end{array}$ & $\mathrm{N}=47$ \\
\hline \multirow[t]{2}{*}{$\begin{array}{l}\text { Do you think your child's speech has } \\
\text { improved while } \\
\text { using devices? }\end{array}$} & $\begin{array}{l}\text { Yes } \\
\text { No }\end{array}$ & $\begin{array}{c}9(13 \%) \\
14(20 \%)\end{array}$ & \\
\hline & No difference & $21(30 \%)$ & $\mathrm{N}=44$ \\
\hline $\begin{array}{l}\text { Do you think your child's social engagement } \\
\text { skills have } \\
\text { improved while using devices? }\end{array}$ & $\begin{array}{l}\text { Yes } \\
\text { No } \\
\text { No difference }\end{array}$ & $\begin{array}{l}13(18 \%) \\
12(17 \%) \\
16(23 \%)\end{array}$ & $\mathrm{N}=46$ \\
\hline
\end{tabular}


watched YouTube, which similarly to watching TV, is a passive receptive process but comes with autonomy in terms of stopping, rewinding and skipping or changing content. Additionally, mobile devices were used for interactive educational applications such as games, and often for connecting with relatives via Skype- an activity seen as an exercise in improving social interaction by $18 \%$ of parents. Studies have shown that socially contingent media (i.e. with appropriate content, timing and intensity) such as videophone applications are as effective as real-life encounters in teaching language to children 2 years and older because they allow responses to children's actions and may facilitate more retention of taught material $[9,10]$ Similarly, the use of interactive media such as learn-to-read applications using IPads ${ }^{\star}$ and electronic books can help improve early literacy skills ${ }^{11}$. There is however more to be gleaned on the effects of these devises on infants and toddlers under 2. Moreover, given the age range of the study sample and the prevalence of answers as to when the devices were used and why, relevant research has dubbed mobile use of media devices while outdoors and when the caregiver was otherwise occupied as "shut-up toys" [11,12]. Consequently, when these devices are used for the aforementioned purposes, they replace other potentially interactive and helpful activities, like traditional play, reading and, parent-child interactions [10,13]. Analysis of parent perceptions revealed widespread tolerance for portable media use despite significant acknowledgement of potential harmful effects. There is evidence, largely from western studies, on the popularity of mobile media devices and their use at a young age. Kabali, et al. [2] reported that within two years, mobile device ownership and screen time quadrupled in the United States, where one third of children below the age of 2 owned a device. Likewise, parent rationale for allowing children access to these devices included keeping the child calm while in public or while doing chores [2].

This study is the first to focus on children below 2 years of age, which is the cutoff used by the latest AAP recommendations for allowing child exposure to media, in a developing country. The strikingly prevalent exposure to mobile media in this Middle Eastern and educated group, together with the aforementioned study [2] conducted in the States, highlights the need for more research investigating possible outcomes of early exposure, and subsequently forming new guidelines specifically for this age group. While there is a persistent need to know the actual effect of early mobile screen time on children, this cross-sectional study must be followed by a larger sampling and subsequently, a longitudinal study to look at developmental outcomes. With the universal application of technology and use of the internet, children in different parts of the world are being increasingly exposed to the same online material. A large prospective multi-national study in diverse populations would prove useful and prudent in developing new, possibly universal, guidelines on media device use in children under 2 years of age.

\section{Summary}

This cross-sectional study investigates parent perception, and prevalence of portable device exposure and use among children two years and younger.

\section{What's Known on This Subject}

The use of portable media devices is a common phenomenon among young children. The AAP discourages use by children younger than 2 years old. Research indicates both positive and negative longterm impacts on developmental milestones.

\section{What This Study Adds}

This study offers a unique perspective on prevalence of use and exposure to portable devices among children younger than 2 years and parent perceptions of device use in a developing country.

\section{Contributors' Statement}

Dr. Heba Al-Rayess conceptualized and designed the study including the data collection instrument, collected data and carried out the initial analyses, and drafted and revised the manuscript.

Dr. Zavi Lakissian conceptualized and designed the study including the data collection instrument, coordinated and supervised the analyses and drafted, reviewed and revised the manuscript.

Dr. Rose-Mary Boustany aided in conceptualizing and designing the study including the data collection instrument, edited and revised the manuscript.

Dr. Rana Sharara-Chami conceptualized and designed the study including the data collection instrument, collected, coordinated and supervised data collection and analyses; reviewed and revised the manuscript.

\section{Funding Sources}

There was no external funding for this manuscript.

\section{Financial Disclosure}

The authors have no financial relationships relevant to this article to disclose.

\section{Conflict of Interest}

The authors have no potential conflicts of interest to disclose.

\section{References}

1. American Academy of Pediatrics (2011) Policy statement: Media use by children younger than 2 years. Pediatrics 128: $1040-1045$.

2. Kabali HK, Irigoyen MM, Nunez-Davis R, Budacki JG, Mohanty SH, et al. (2015) Exposure and Use of Mobile Media Devices by Young Children. Pediatrics 136:10441050

3. Zimmerman FJ, Christakis DA, Meltzoff AN (2007) Television and DVD/video viewing in children younger than 2 years. Arch Pediatr Adolesc Med 161: 473-479. [Crossref]

4. Zimmerman FJ, Christakis DA (2005) Children's television viewing and cognitive outcomes: a longitudinal analysis of national data. Arch Pediatr Adolesc Med 159: 619-625.

5. Pagani LS, Fitzpatrick C, Barnett TA, Dubow E (2010) Prospective associations between early childhood television exposure and academic, psychosocial, and physical well-being by middle childhood. Arch Pediatr Adolesc Med 164: 425-431

6. Christakis DA (2014) Interactive media use at younger than the age of 2 years: time to rethink the American Academy of Pediatrics guideline? JAMA Pediatr 168: 399-400. [Crossref]

7. Kwok K, Ghrear S, Li V, Haddock T, Coleman P, et al. (2016) Children Can Learn New Facts Equally Well From Interactive Media Versus Face to Face Instruction. Front Psychol 7: 1-10.

8. Bedford R, Saez de Urabain IR, Cheung CHM, Karmiloff-Smith A, Smith TJ (2016) Toddlers' Fine Motor Milestone Achievement Is Associated with Early Touchscreen Scrolling. Front Psychol 7: 1-8

9. Roseberry S, Hirsh-Pasek K, Golinkoff RM (2014) Skype me! Socially Contingent Interactions Help Toddlers Learn Language. Child Dev 85: 956-970

10. Radesky JS, Schumacher J, Zuckerman B (2015) Mobile and interactive media use by young children: the good, the bad, and the unknown. Pediatrics 135: 1-3. [Crossref]

11. Kucirkova N (2014) iPads in Early Education: Separating Assumptions and Evidence. Front Psychol 5: 715. 
12. Radesky JS, Kistin CJ, Zuckerman B, Nitzberg K, Gross J, et al. (2014) Patterns of Mobile Device Use by Care-givers and Children During Meals in Fast Food Restaurants. Pediatrics 133: e843-849.
13. Krikorian HL, Pempek TA, Murphy LA, Schmidt ME, Anderson DR (2009) The Impact of Background Television on Parent-Child Interaction. Child Dev 80: 13501359.

Copyright: (C2019 Sharara-Chami R. This is an open-access article distributed under the terms of the Creative Commons Attribution License, which permits unrestricted use, distribution, and reproduction in any medium, provided the original author and source are credited. 